\title{
LingTera
}

Volume 2 - Nomor 1, Mei 2015, (12 - 26)

Available online at LingTera Website: http://journal.uny.ac.id/index.php/ljtp

\section{VARIASI KELUASAN MAKNA INTERPERSONAL TEKS "LASKAR PELANGI" BERBAHASA INDONESIA, INGGRIS, DAN MELAYU}

\author{
Apriliana Hapsari ${ }^{1)}$, Asruddin Barori Tou ${ }^{2)}$ \\ BBC Branch of Pati ${ }^{1)}$, Universitas Negeri Yogyakarta ${ }^{2)}$ \\ lee_haps@yahoo.com ${ }^{1)}$, asruddintou@yahoo.com ${ }^{2)}$
}

\begin{abstract}
Abstrak
Penelitian ini bertujuan untuk mendeskripsikan variasi keluasan makna interpersonal pada teks "Laskar Pelangi" berbahasa Indonesia, Inggris, dan Melayu serta faktor-faktor yang mendorong terjadinya tingkat variasi keluasan makna tersebut. Penelitian ini merupakan penelitian deskriptif kualitatif dengan objek penelitian adalah variasi keluasan makna interpersonal yang terealisasi dalam sistem gramatika MOOD pada tiap klusa dari ketiga teks multitranslasi. Data dianalisis dengan teknik hubung banding dengan membandingkan masing-masing klausa dari ketiga teks tersebut. Hasil penelitian menunjukkan tingginya tingkat variasi keluasan makna interpersonal pada T1:T2, sebesar 23,89, dan rendahnya tingkat variasi tersebut pada T1:T3, sebesar 2,82. Tingginya tingkat variasi disebabkan penambahan klausa pada T2, pengaruh skrip cerita film, faktor tujuan, serta faktor pembaca T2. Rendahnya tingkat variasi disebabkan persamaan akar bahasa dan budaya antara T1 dan T3 serta faktor tujuan penerjemahan.
\end{abstract}

Kata kunci: sistem gramatika MOOD, variasi keluasan makna interpersonal

\section{THE INTERPERSONAL MEANING BREADTH VARIATIONS ON MULTILINGUAL TRANSLATION TEKS “LASKAR PELANGI” IN BAHASA INDONESIA, ENGLISH, AND MALAY}

\begin{abstract}
This study is aimed to describe the interpersonal meaning breadth variations on multilingual translation teks "Laskar Pelangi" in bahasa Indonesia, English, and Malay also to explore the motivating factors that occur inside those variations. This study was a descriptive qualitative research study. The object was interpersonal meaning breadth variations that were showed by the MOOD grammatical system in the clauses of the multilingual translation texts. The data were analyzed by comparing the realization of functional elements of the MOOD grammatical system in each clause of the text. The results of this study show that variations in interpersonal meaning breadth of T1:T2 are high, 23.89 whereas the variations of T1:T3 are low, 2.82. For T1:T2, the variation in interpersonal meaning breadth is high, because of the addition of clauses in T2, the influence of movie script, the translation purpose, and the target text's readers. Meanwhile, for T1:T3, the variation in interpersonal meaning breadth is low because of the non-existence of new clauses in T2, the same language root of Indonesian and Malay and the purpose of translation.
\end{abstract}

Keywords: MOOD grammatical system, interpersonal menaing breadth variation 


\section{LingTera, 2 (1), Mei 2015 - 13}

Apriliana Hapsari, Asruddin Barori Tou

\section{PENDAHULUAN}

Penerjemahan merupakan aktivitas penciptaan kembali makna (recreating meaning) ke dalam kemasan yang bebeda. Proses penciptaan kembali makna menjadikan teks terjemahan memiliki realisasi yang berbeda dengan teks sumber. Oleh karena itu, aktivitas penerkjemahan selalu menghasilkan teks baru yang berbeda dengan teks sumber.

Perbedaan realisasi makna pada teks terjemahan menunjukkan bahwa aktivitas penerjemahan merupakan salah satu bentuk komunikasi yang melibatkan sistem semiotik yang selalu beroperasi dalam konteks. Konteks dalam aktivitas penerjemahn dapat berupa sistem bahasa, tujuan penerjemahan, pembaca sasaran, faktor sosial budaya ataupun religi. Konteks tersebut dapat mempengaruhi realisasi makna dalam teks terjemahan. Makna tersebut dapat terealisasi sama ataupun berbeda dengan teks sumber.

Realisasi makna yang berbeda inilah yang merupakan dasar konsep variasi dalam penerjemahan. Konsep variasi menunjukkan bahwa dalam penerjemahan tidak mungkin terwujud kesepadan (equivalence), karena tiap penerjemah menginterpretasi suatu teks secara berbeda, dengan berlandaskan latar belakang pengetahuan kebahasaan mereka masing-masing. Selain itu, faktor pembaca sasran dan tujuan penerjemahan yang berbeda dengan pembaca teks sumber dan tujuan penulisan teks sumber juga akan menimbulkan hadirnya pebedaan realisasi makna.

Realisasi makna yang berbeda ini ditunjukkan oleh teks Laskar Pelangi karya Andrea Hirata (T1), Rainbow Troops karya Angie Kilbane (T2), dan Lasykar Pelangi karya Ida Munira Abu Bakar (T3). Ketiga teks ini merupakan teks yang memilki hubungan translasional (saling berpenerjemahan). Ketiga teks ini menunjukkan adanya perbedaan realisasi makna. Hal tersebut ditunjukkan dengan bertambahnya jumlah bab pada T2. Penambahan tersebut dapat mengindikasikan bahwa penerjemah melakukan penambahan realisasi klausa, yang berarti penerjemah melakukan perubahan terhadap sifat makna, yang berupa keluasan. Variasi keluasan makna inilah yang menjadi fokus utama dalam penelitian ini.

Pada penelitian ini, variasi keluasan makna dianalisis dengan menggunakan pendekatan systemic functional grammar yang dikemukakan oleh Halliday. Dalam teori ini, Halliday (2004, p.29) membagi makna manjadi tiga berdasarkan fungsinya, yaitu makna ideasional, interpersonal, dan tekstual. Teori tersebut menjelaskan bahwa satu unit klausa dapat merealisasikan satu unit makna ideasional, interpersonal, dan tekstual. Akan tetapi, penelitian ini hanya akan berfokus pada makna interpersonal, khususnya wujud dan tingkat variasi keluasan makna interpersonal pada T1, T2, dan T3.

Tujuan penelitian ini adalah untuk mendeskripsikan bagaimana variasi keluasan makna interpersonal ditunjukkan oleh T1, T2, dan T3. Selain itu, penelitian ini juga bertujuan untuk mengungkap faktor-faktor yang mendorong tinggi/rendahnya tingkat variasi keluasan makna interpersonal antara T1:T2 dan T1:T3.

\section{METODE}

Penelitian ini adalah penelitian deskriptif kualitatif yang bertujuan untuk menjelaskan salah satu fenomena penerjemahan. Fenomena tersebut dianalisis berdasarkan konsep variasi makna. Jadi, penelitian ini merupakan penelitian yang menjelaskan tentang; (1) tingkat dan wujud variasi keluasan makna interpersonal yang ditunjukkan oleh teks translasional multibahasa; teks Laskar Pelangi karya Andrea Hirata, Rainbow Troops karya Angi Kilbane, dan Laskar Pelangi karya Ida Munira Abu Bakar, dan (2) faktor-faktor yang mendorong tinggi/rendahnya tingkat variasi keluasan makna interpersonal antara T1:T2 dan T1:T3.

Penelitian ini merupakan penelitian yang menggunakan data kepustakaan sebagai bahan utamanya. Oleh karena itu, penelitian dapat dilakukan di perpustakaan ataupun di rumah. Penelitian berlangsung selama kurang lebih setahun.

Subjek penelitian adalah teks, berupa novel, multitranslasi yang ditulis dalam tiga bahasa; Laskar Pelangi karya Andrea Hirata dalam Indonesia, Rainbow Troops karya Angie Kilbane dalam bahasa Inggris, dan Lasykar Pelangi karya Ida Munira Abu Bakar dalam bahasa Melayu. Objek penelitian ini adalah keluasan makna interpersonal yang terealisasi dalam setiap klausa yang terdapat dalam teks multitranslasi tiga bahasa tersebut.

Data dikumpulkan dengan menyimak dan mencatat dalam waktu yang bersamaan. Ketiga teks dibaca secara berulang-ulang, kemudian setiap kalusa dicatat dan dimasukkan ke dalam tabel dan diberi kode yang telah ditentukan. Selain itu, data diperoleh pula dari wawancara. Wawancara dilakukan secara langsung dengan kepala editor PT. Bentang Pustaka, Bp. Salman Faridi dan secara tidak langsung, melalui email, 
dengan penulis Laskar Pelangi, Andrea Hirata. Data dari wawancara digunakan untuk mengetahui faktor-faktor yang mendorong tinggi/rendahnya tingkat variasi keluasan makna interpersonal antara $\mathrm{T} 1, \mathrm{~T} 2$, dan $\mathrm{T} 3$.

Instrumen penelitian adalah peneliti itu sendiri, berlandaskan pada teori systemic functional grammar yang dikemukakan oleh Halliday dan teori penerjemahan translatik yang dikemukakan oleh Asruddin. B. Tou. Berdasarkan teori tersebut, dihasilkan tabel parameter sebagai instrumen untuk mengklasifikasi dan menganalisis tingkat variasi keluasan makna interpersonal.

Tabel parameter tersebut memiliki skala nilai 0-6. Variasi bernilai 0, jika realisasi elemen fungsional sistem gramatika MOOD antar T1, T2, dan T3 sama atau tidak ada perubahan. Variasi bernilai 6 , jika terdapat penambahan ataupun penghilangan realisasi makna setingkat klausa pada T1, T2, ataupun T3. Skala 1-5 menunjukkan adanya jumlah perbedaan (penambahan dan pengurangan) realisasi elemen fungsional. Bernilai 1 jika terdapat satu perbedaan realisasi elemen, 2 jika terdapat dua perbedaan, 3 jika terdapat tiga perbedaan, 4 jika terdapat empat perbedaan, dan 5 jika terdapat lima atau lebih dari lima elemen fungsional yang berbeda.

Keabsahan data yang digunakan pada penelitian ini adalah konsep trianggulasi; sumber, metode, penyidik, dan teori. Validasi data yang digunakan adalah member of validation dan expert judgement untuk menilai kualitas penelitian.

Teknik analisis data yang dilakukan adalah teknik analisis hubung banding, dengan cara membandingkan elemen-elemen pembentuk makna interpersonal yang terdapat pada tiap-tiap satuan klausa dalam T1, T2, dan T3. Selain itu, dilakukan pula interpretasi terhadap data yang diperoleh dari hasil wawancara untuk menemukan faktor-faktor yang mendorong terjadinya va- riasi keluasan makna interpersonal antara $\mathrm{T} 1$, T2, dan T3.

\section{HASIL DAN PEMBAHASAN}

Berdasarkan analisis data, diperoleh beberapa hasil dalam penelitian ini. Hasil teresebut yaitu:

\section{Wujud Variasi Keluasan Makna Interperso- nal T1:T2}

Wujud variasi keluasan makna interpersonal T1:T2 cukup variatif. Hal ini berarti, tiap nilai variasi terwakili atau terealisasi dalam kedua teks translasional. Akan tetapi, variasi paling dominan adalah variasi enam. Berikut ini ditunjukkan wujud realisasi dari variasi keluasan makna interpersonal T1:T2 secara lebih jelas.

\section{Variasi Nol}

Klausa translasional $\mathrm{T} 1$ dan $\mathrm{T} 2$ bernilai variasi nol jika kedua klausa tersebut tidak menunjukkan adanya penembahan atau pengurangan realisasi elemen fungsional sistem gramatika MOOD. Berikut ini ditunjukkan beberapa contoh klausa bernilai variasi nol.

\section{1/2 Sebatang pohon filicium tua meneduhiku}

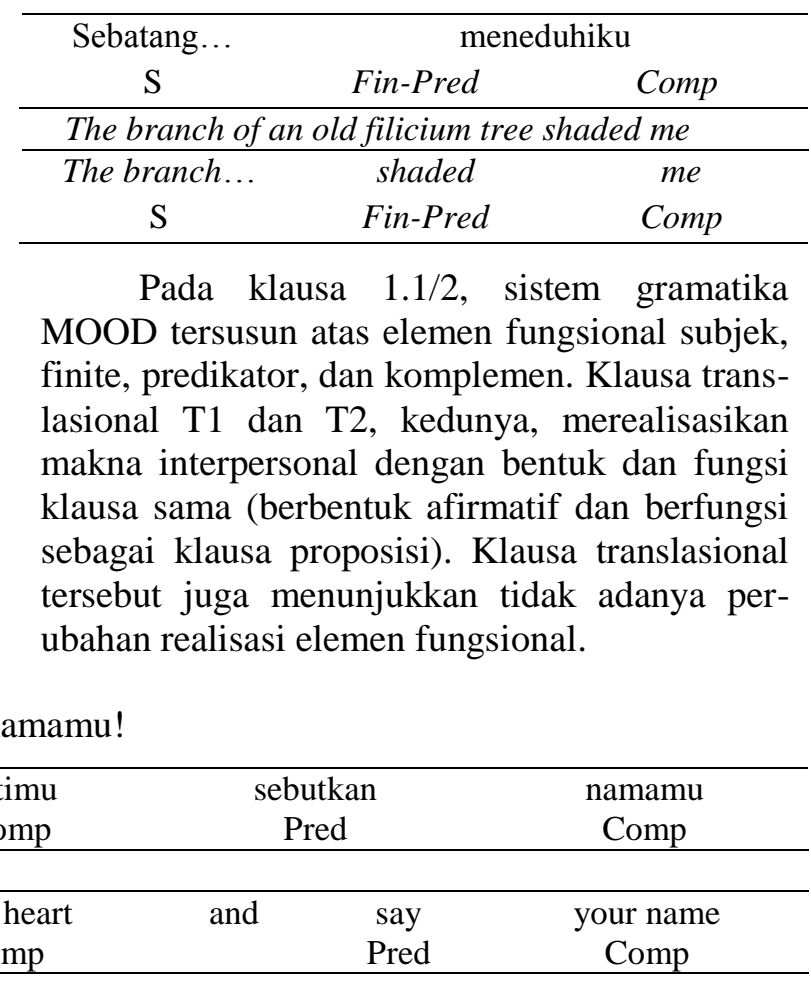

Klausa translasional 1.3/136 juga menunproposal. Realisasi elemen fungsional dari kedua klausa tersebut juga tidak mengalami perubahan.

1.3/136 Ayolah anakku, kuatkan hatimu, sebutkan namamu

\begin{tabular}{|c|c|c|c|c|}
\hline $\begin{array}{l}\text { Ayolah,... } \\
\text { Pred }\end{array}$ & $\begin{array}{l}\text { kuatkan } \\
\text { Pred }\end{array}$ & $\begin{array}{l}\text { hatimu } \\
\text { Comp }\end{array}$ & $\begin{array}{l}\text { sebutkan } \\
\text { Pred }\end{array}$ & $\begin{array}{l}\text { namamu } \\
\text { Comp }\end{array}$ \\
\hline \multicolumn{5}{|c|}{ Come on son, strengthen your heart and say your name } \\
\hline $\begin{array}{c}\text { Come on... } \\
\text { Pred }\end{array}$ & $\begin{array}{l}\text { strengthen } \\
\text { Pred }\end{array}$ & $\begin{array}{l}\text { your heart } \\
\text { Comp }\end{array}$ & $\begin{array}{l}\text { say } \\
\text { Pred }\end{array}$ & $\begin{array}{l}\text { your name } \\
\text { Comp }\end{array}$ \\
\hline
\end{tabular}
jukkan bentuk dan fungsi klausa yang sama antara T1 dan T2. Klausa tersebut berbentuk klausa imperatif dan berfungsi sebagai kluasa 


\section{LingTera, 2 (1), Mei 2015 - 15}

Apriliana Hapsari, Asruddin Barori Tou

1.4/316 Puluhan mobil mewah berderet di depan sekolah dan ratusan anak orang kaya mendaftar

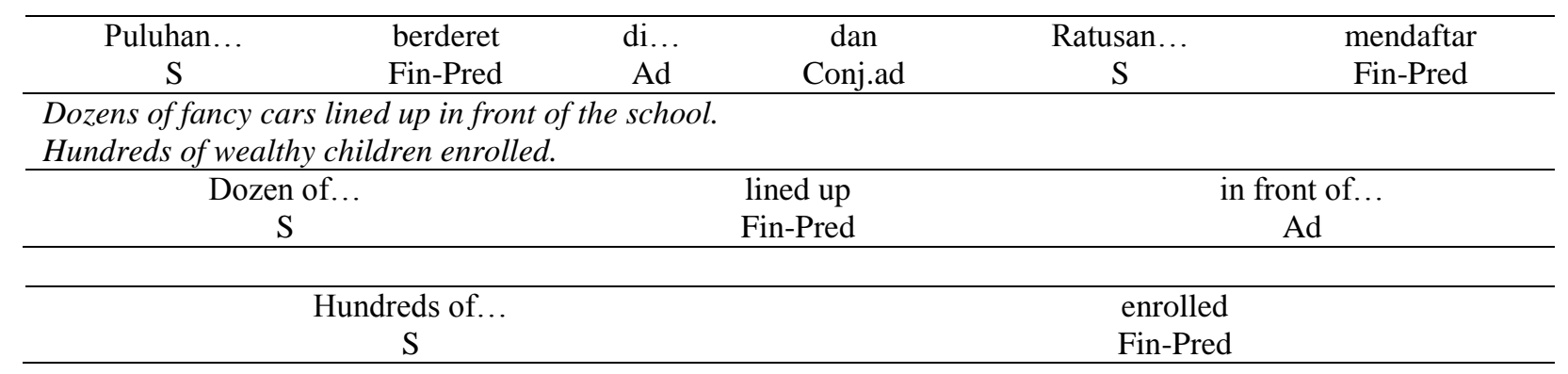

Secara sekilas, klausa translasional 1.4/316 memiliki realisasi yang berbeda. Klausa T1 merupakan klausa kompleks dengan dua klausa sederhana, sedangkan klausa T2 adalah dua klausa sederhana. Akan tetapi, jika lebih diamati, klausa translasional tersebut tidak memiliki realisasi yang berbeda. Klausa T2 hanya menghilangkan realisasi kata hubung 'dan', tetapi tidak mengubah realisasi klausa. Oleh karen aitu, klausa translasional tersebut memiliki variasi nol.

Variasi Satu

Klausa translasional $\mathrm{T} 1$ dan $\mathrm{T} 2$ bernilai satu jika terdapat perbedaan realisasi satu buah elemen fungsional sistem gramatika MOOD. Elemen yang bertambah ataupun berkurang dapat berupa elemen subjek, predikator, komplemen, adjunct, mood adjunct, ataupun comment adjunct. Berikut ini ditunjukkan beberapa contoh klausa yang bernilai variasi satu.

1.22/77 Aku dan Lintang di samping kiri dan kanannya.

\begin{tabular}{|c|c|c|}
\hline $\begin{array}{c}\text { Aku dan Lintang } \\
\text { S } \\
\end{array}$ & & $\begin{array}{l}\text { nping... } \\
\text { n-Ad }\end{array}$ \\
\hline \multicolumn{3}{|c|}{ Lintang and I sat on either side of her } \\
\hline $\begin{array}{l}\text { Lintang and I } \\
\text { S }\end{array}$ & $\begin{array}{c}\text { sat } \\
\text { Fin-Pred }\end{array}$ & $\begin{array}{c}\text { on either... } \\
\text { Ad }\end{array}$ \\
\hline
\end{tabular}

Klausa translasional $1.22 / 77$ menunjukkan penambahan realisasi elemen predikator pada T2. Pada klausa tersebut, penerjemah memperjelas makna dengan menambahi realisasi verba "sit" pada klausa T2, karena pada klausa T1, realisasi kata duduk hanya bisa ditangkap secara implisit. Pembaca T2 yang kurang pemahaman tentang lomba kecerdasan (cerdas cermat) di Indonesia tidak akan mampu menangkap makna implisit tersebut, sehingga penerjemah mereali-sasikan makna tersebut secara eksplisit.
1.19/246 Pakaiannya hanya selambar kain panjang yang dililit-lilitkan

\begin{tabular}{cccc}
\hline Pakainnya & hanya & selembar... & yang... \\
S & Mood ad & Fin-Comp & Ad \\
\hline
\end{tabular}

He wore nothing more than a sheet of fabric wrapped around his body

\begin{tabular}{cccc}
\hline $\mathrm{He}$ & wore & nothing & more than... \\
$\mathrm{S}$ & Fin-Pred & Comp & Ad \\
\hline
\end{tabular}

Contoh klausa translasional 1.19/246 menunjukkan adanya perbedaan subjek yang digunakan, sehingga terjadi pula perubahan pada realisasi predikator Pada klausa tersebut T1 merealisasikan "pakaiannya hanya selembar kain panjang yang dililitkan...". Klausa ini dapat dipersepsikan bahwa seseorang tidak memakai apapun kecuali selembar kain. Persepsi inilah yang direalisasikan oleh penerjemah pada $\mathrm{T} 2$ "he wore nothing more than a sheet...". T1 lebih mengutamakan objek yang dipakai sedangkan T2 lebih mengutamakan subjek yang memakai. Konsep T2 tersebut sesuai dengan pola bahasa bahasa Inggris yang selalu mewajibkan hadirnya subjek pada tiap klausa serta lebih utamanya penggunaan klausa aktif daripada pasif. Pada bahasa Indonesia, klausa pasif lebih sering digu-nakan, sehingga objek klausa lebih dipentingkan.

1.19/144 Malam pun turun

\begin{tabular}{ccc}
\hline $\begin{array}{c}\text { Malam } \\
\mathrm{S}\end{array}$ & $\begin{array}{c}\text { pun } \\
\text { Mood ad }\end{array}$ & $\begin{array}{c}\text { turun } \\
\text { Fin-Pred }\end{array}$ \\
\hline \multirow{2}{*}{ Night fell } & \\
\hline Night & \\
$\mathrm{S}$ & & \\
\hline
\end{tabular}

Klausa translasional 1.19/144 menunjukkan adanya penghilangan realisasi mood adjunct yang berupa tingkat intensity pada T2.

1.22/113 Pertanyaan pertama bergema.

\begin{tabular}{c|c}
\hline Pertanyaan... & bergema \\
$\mathrm{S}$ & Fin-Pred \\
\hline
\end{tabular}




\section{LingTera, 2 (1), Mei 2015 - 16}

Apriliana Hapsari, Asruddin Barori Tou

The first question reverberated throughout the room.

\begin{tabular}{ccc}
\hline The first... & reverberated & throughout... \\
$\mathrm{S}$ & Fin-Pred & Ad \\
\hline
\end{tabular}

Klausa translasional 1.22/113 memiliki perbedaan realisasi elemen adjunct. Penambahan adjunct pada klausa tersebut dimaksudkan untuk memberikan keterangan tambahan dan memperjelas makna, sehingga lebih mudah dimengerti oleh pembaca $\mathrm{T} 2$.

1.22/335 Melihatku demikian gusar, Lintang tersenyum kecil padaku.

\begin{tabular}{cccc|}
\hline Melihatku... & Lintang & tersenyum... & padaku \\
Ad & $\mathrm{S}$ & Fin-Pred & $\mathrm{Ad}$ \\
\hline
\end{tabular}

Seeing my anger, Lintang gave me a little smile.

\begin{tabular}{ccccc}
\hline Seeing... & Lintang & gave & $m e$ & a little... \\
Ad & $\mathrm{S}$ & Fin-Pred & Comp & Ad \\
\hline
\end{tabular}

Pada klausa translasional 1.22/335 terjadi penambahan realisasi komplemen pada T2. Hadirnya komplemen merupakan akibat dari realisasi verba transitif "give" pada T2. Pada klausa $\mathrm{T} 1$ verba yang dipakai adalah verba intransitive "tersenyum". Realisasi "tersenyum kecil padaku" diubah menjadi "give me a little smile" oleh penerjemah. Oleh karena itu, klausa T2 membutuhkan realisasi komplemen sedangkan T1 tidak perlu komplemen.

1.12/61 Pagi itu giliran aku dan Syahdan berangkat ke toko bobrok itu.

\begin{tabular}{|c|c|c|}
\hline $\begin{array}{l}\text { Pagi itu } \\
\text { Ad }\end{array}$ & $\begin{array}{l}\text { giliran... } \\
\text { Fin-Comp }\end{array}$ & $\begin{array}{l}\text { berangkat... } \\
\text { Ad }\end{array}$ \\
\hline \multicolumn{3}{|c|}{$\begin{array}{l}\text { That morning it was mine and Syahdan's turn to visit } \\
\text { that grungy shop. }\end{array}$} \\
\hline That & was & to... \\
\hline $\mathrm{Ad}$ & Fin & Comp \\
\hline
\end{tabular}

Klausa translasional 1.12/61, menunjukkan adanya penambahan subjek pada klausa T2. Pada tata bahasa bahasa Indonesia pola klausa T1 pada klausa 1.12/61 merupakan hal yang wajar dan tepat. Akan tetapi, pola klausa tersebut tidak bisa diaplikasikan pada bahasa Inggris. Bahasa Inggris membutuhkan realisasi subjek untuk membentuk klausa yang hanya terdiri dari nomina.

1.19/278 Bagaimanapun pesan ini mengandung pertaruhan reputasi yang pasti.

\begin{tabular}{|c|c|c|c|}
\hline $\begin{array}{c}\text { Bagaimanapun } \\
\text { Comm.ad }\end{array}$ & $\begin{array}{c}\text { pesan... } \\
\text { S }\end{array}$ & $\begin{array}{l}\text { mengandung } \\
\text { Fin-Pred }\end{array}$ & $\begin{array}{c}\text { pertaruhan... } \\
\text { Comp }\end{array}$ \\
\hline \multicolumn{4}{|c|}{ That message held the fate of his reputation. } \\
\hline $\begin{array}{c}\text { That... } \\
\text { S }\end{array}$ & & & $\begin{array}{l}\text { the fate... } \\
\text { Comp }\end{array}$ \\
\hline
\end{tabular}

Klausa translasional 1.19/278 menunjukkan adanya penghilangan realisasi comment adjunct pada klausa T2, sehingga T2 memberikan kesan lebih netral (tidak terdapat pandangan yang bersikap personal). Realisasi kata "bagaimanapun" pada T1 (klausa 1.19/278) lebih memberi kesan personal jika dibandingkan klausa T2 yang hanya berfungsi sebagai klausa proposisi yang berfungsi untuk memberikan informasi.

\section{Variasi Dua}

Klausa translasional bernilai variasi dua jika terdapat penambahan ataupun pengurangan realisasi elemen fungsional sistem gramatika MOOD sebanyak dua buah elemen. Di bawah ini disajikan beberapa contoh klausa bernilai variasi dua.

1.12/94 Inilah pasar ikan.

\begin{tabular}{cc}
\hline Inilah & pasar ikan \\
$\mathrm{S}$ & Fin-Comp \\
\hline
\end{tabular}

We arrived at the fish market

\begin{tabular}{ccc}
\hline $\mathrm{We}$ & arrived & at... \\
$\mathrm{S}$ & Fin-Pred & Ad \\
\hline
\end{tabular}

Klausa 1.12/94 menunjukkan adanya penambahan adjunct dan predikator karena penggunaan subjek yang berbeda antara T1 dan T2. T1 dan T2 merupakan klausa yang bercerita tebtang pasar ikan. Akan tetapi, penulis dan penerjemah memiliki cara yang berbeda untuk mengawali cerita tentang pasar ikan (fish market) tersebut. Penulis lebih menonjolkan kata tunjuk untuk memperkenalkan pasar ikan, karena pada klausa sebelumnya penulis telah menggambarkan pasar ikan. Jadi klausa "inilah pasar ikan" merupakan suatu simpulan dari penjelasan penulis pada klausa sebelumnya. Penerjemah mengungkapkan ide tersebut dengan menggunakan subjek orang ketiga jamak "we arrived at fish market" karena klausa sebelumnya bercerita tentang perjalanan naik sepeda menuju pasar ikan. Meskipun realisasi dari 
kedua klausa berbeda, fungsi dari kedua klausa sama, yaitu sebagai sebuah pengantar untuk menjelaskan pasar ikan secara lebih detail.

1.12/50 Namun, tugas membeli kapur adalah pekerjaan yang jauh lebih horor.

\begin{tabular}{ccccc}
\hline $\begin{array}{c}\text { Namun } \\
\text { Conj.ad }\end{array}$ & $\begin{array}{c}\text { tugas... } \\
\mathrm{S}\end{array}$ & $\begin{array}{c}\text { adalah } \\
\text { Fin }\end{array}$ & $\begin{array}{c}\text { pekerjaan... } \\
\text { Comp }\end{array}$ \\
\hline $\begin{array}{c}\text { But the job } \\
\text { horrifying. }\end{array}$ & & & & \\
& & & \\
\hline But & the $\ldots$ & is & even & more... \\
Conj.ad & $\mathrm{S}$ & Fin & Mood ad & Ad \\
\hline
\end{tabular}

Klausa 1.12/50 menunjukkan penambahan realisasi elemen mood adjunct dan adjunct pada T2. Pada klausa 1.12/50, T1 lebih menonjolkan nomina (komplemen) sedangkan T2 hanya merealisasikan dalam mood adjunct dan adjunct. Pada klausa T2 penerjemah tidak merealisasikan nomina karena nomina tersebut sama dengan subjek (pengulangan subjek). Penerjemah lebih memilih untuk menggunakan adjektiva untuk menjelaskan subjek. Dalam hal ini penerjemah memilih untuk membentuk klausa yang lebih efektif.

Variasi Tiga

Keluasan makna interpersonal memiliki nilai variasi tiga apabila terdapat perbedaan (panambahan atau pengurangan) tiga buah elemen fungsional sistem gramatika MOOD pada klausa translasional. Di bawah ini disajikan beberapa contoh klausa bernilai variasi tiga.

1.11/191 Mahar semakin terpojok dan merasa bersalah.

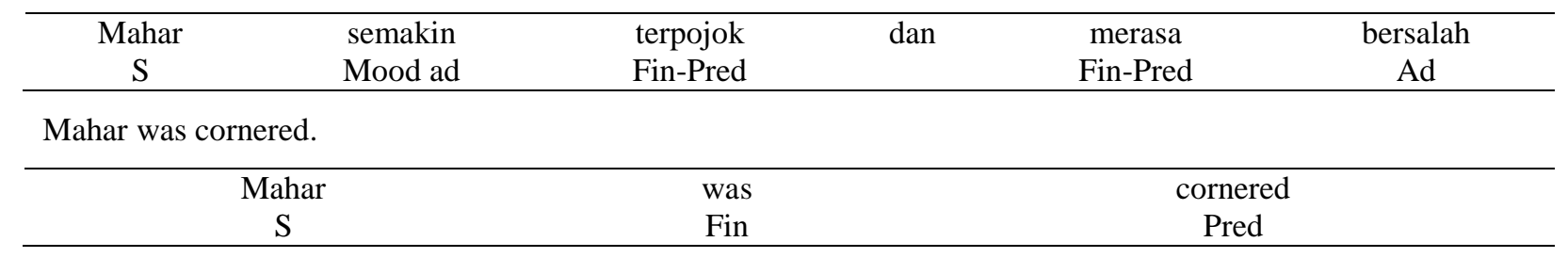

Klausa 1.11/191 memperlihatkan dua klausa translasional yang memiliki bentuk dan fungsi yang sama, tapi memiliki perbedaan realisasi elemen fungsional sistem gramatika MOOD. Klausa T1 merupakan klausa kompleks dengan dua klausa sederhana sedangkan klausa T2 merupakan klausa sederhana. Klausa T1

1.24/384 Anggota Societeit mengangguk-angguk setuju.

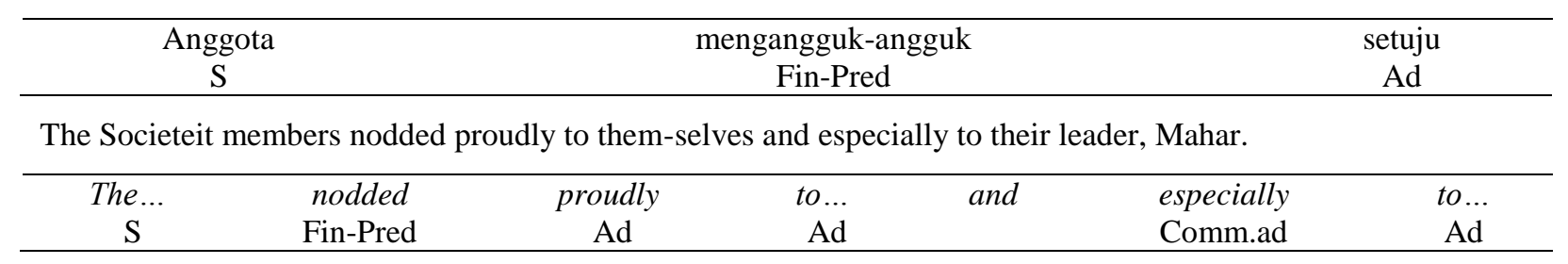

Klausa translasional 1.24/384 memiliki bentuk dan fungsi sama, tapi realisasi elemen fungsional berbeda. Klausa T1 merupakan klausa sederhana sedangkan klausa T2 merupakan klausa kompleks dengan dua klausa sederhana. Pada klausa T2 terdapat realisasi comment adjunct dan adjunct yang memberikan keterangan tambahan, sedangkan pada klausa T1 realisasi elemen makna interpersonal tersebut tidak ada.

\section{Variasi Empat}

Keluasan makna interpersonal pada klausa translasional memiliki nilai variasi empat memiliki dua realisasi finite dan predikator, sedangkan klausa T2 hanya memilki satu relisasi finite dan predikator. Selain itu, pada klausa T1 terdapat pula realisasi mood adjunct yang menyatakan intensitas makna yang tidak terealisasi pula pada klausa $\mathrm{T} 2$. apabila terdapat perbedaan realisasi elemen fungsional sistem gramatika MOOD sebanyak empat buah.

1.22/306 Si Drs bersungut-sungut, ia merasa di atas angin.

\begin{tabular}{ccccc}
\hline Si... & bersungut-sungut & ia & merasa & di... \\
S & Fin-Pred & S & Fin-Pred & Ad \\
\hline
\end{tabular}

Drs. Zulfikar grumbled.

\begin{tabular}{cc}
\hline Drs. Zulfikar & grumbled \\
S & Fin-Pred \\
\hline
\end{tabular}

Klausa translasional 1.22/306 memiliki bentuk klausa afirmatif atau deklaratif dan 


\section{LingTera, 2 (1), Mei 2015 - 18}

Apriliana Hapsari, Asruddin Barori Tou

berfungsi sebagai klausa proposisi (memberikan informasi). Meskipun bentuk dan fungsi klausa translasional tersebut sama, realisasi klausa T1 dan T2 berbeda. Klausa T1 merupakan klausa kompleks dengan dua klausa sederhana yang dihubungkan dengan tanda koma. Klausa T2 merupakan klausa sederhana. Pada klausa T2 realisasi klausa "ia merasa di atas angin" tidak terealisasi. Klausa T2 hanya merealisasikan satu klausa sederhana pada klausa T1. Berkurangnya satu klausa sederhana menjadikan klausa translasional tersebut memiliki realisasi elemen yang tidak sama dan bernilai variasi empat.
Variasi Lima

Keluasan makna interpersonal memiliki nilai variasi lima apabila pada klausa translasional terdapat perbedaan (penambahan ataupun pengurangan) realisasi elemen fungsional sistem gramatika MOOD sebanyak lima atau lebih dari lima buah elemen. Variasi lima ini bisa terjadi apabila klausa kompleks pada T1 terealisasi menjadi satu klausa sederhana pada $\mathrm{T} 2$ atau sebaliknya.

1.5/350 Samson tak peduli, ia tetap menekan belahan bola tenis itu tanpa perasaan.

\begin{tabular}{|c|c|c|c|c|c|c|}
\hline $\begin{array}{c}\text { Samson } \\
\text { S }\end{array}$ & $\begin{array}{l}\text { tak peduli } \\
\text { Fin-Pred }\end{array}$ & $\begin{array}{r}\text { ia } \\
\mathrm{S}\end{array}$ & $\begin{array}{c}\text { tetap } \\
\text { Mood ad }\end{array}$ & $\begin{array}{c}\text { menekan } \\
\text { Fin-Pred }\end{array}$ & $\begin{array}{c}\text { belahan... } \\
\text { Comp }\end{array}$ & $\begin{array}{c}\text { tanpa... } \\
\text { Ad }\end{array}$ \\
\hline \multicolumn{7}{|c|}{ Samson didn't care } \\
\hline & $\begin{array}{c}\text { Samson } \\
\text { S }\end{array}$ & & & $\begin{array}{l}\text { didn't } \\
\text { Fin }\end{array}$ & & $\begin{array}{l}\text { care } \\
\text { Pred }\end{array}$ \\
\hline
\end{tabular}

Dengan memperhatikan contoh klausa $1.5 / 350$, dapat diketahui dengan jelas bahwa klausa translasional tersebut memiliki perbedaan realisasi elemen fungsional sistem gramatika MOOD. Klausa kompleks dengan dua klausa sederhana pada $\mathrm{T} 1$ hanya direalisasikan menjadi satu klausa sederhana pada T2. Pada T2, tidak ada realisasi klausa "ia tetap menekan...", sehingga terjadi pengurangan realisasi elemen makna interpersonal. Pengurangan satu klausa sederhana menunjukkan realisasi variasi lima pada klausa translasional tersebut.

\section{Variasi Enam}

Variasi enam terjadi apabila terdapat perbedaan satu unit klausa setingkat kalimat atau terjadi penambahan ataupun pengurangan realisasi dari satu unit makna setingkat klausa/kalimat secara utuh. Variasi ini sebagian besar terjadi karena adanya penambahan bab pada T2 yang tidak bersumber dari T1. Penambahan bab tersebut ditunjukkan dengan munculnya 10 bab baru pada novel Rainbow Troops.

1.4/6 N.A. Muslimah Hafsari Hamid binti K.A. Abdul Hamid, atau kami memanggilnya Bu Mus, hanya memiliki selembar ijazah SKP (Sekolah Kepandaian Putri), namun beliau bertekad melanjutkan cita-cita ayahnya-K.A.Abdul Hamid, pelopor sekolah Muhammadiyah di Belitong-untuk terus mengobarkan pendidikan Islam

Bu Mus had just graduated from SKP (Vocational Girls' School), which was only equivalent to junior high school

1.4/7 It wasn't a teaching school, but more of a school to prepare young women to be good wives

1.4/8 There, they learned how to cook, embroider and sew

1.4/9 Bu Mus had been determined to go to the regency capital, Tanjong Pandan, to go to school at SKP so she could get a higher level diploma than that offered by the elementary school where she would teach

1.4/10 Upon graduating from SKP, she was offered a job with PN as the rice warehouse head secretary-a very promising position

1.4/11 She had even been proposed to by the son of a business owner

1.4/12 Bu Mus had been determined to go to the regency capital, Tanjong Pandan, to go to school at SKP so she could get a higher level diploma than that offered by the elementary school where she would teach

1.4/13 Midah, Aini, Izmi and Nurul, her classmates, could not for the life of them understand why Bu Mus had turned down those two attractive offers

1.4/14 Unlike Bu Mus, those four swooped down and seized the opportunity to become PN administrative workers

$1.4 / 13$ "I want to be a teacher," said the fifteen-year-old girl

Klausa-klausa tersebut merupakan contoh realisasi variasi enam. Penerjemah menciptakan klausa-klausa baru tersebut untuk memperjelas deskripsi cerita. 


\section{LingTera, 2 (1), Mei 2015 - 19}

Apriliana Hapsari, Asruddin Barori Tou

Klausa-klausa tersebut merupakan beberapa klausa yang merupakan hasil kreasi atau interpreatasi penerjemah sendiri terhadap karakter bu Mus dalam novel. Klausa tersebut bukan bersumber dari $\mathrm{T} 1$, tapi bersumber dari hasil wawancara serta interpretasi dari penerjemah sendiri terhadap keseluruhan klausa yang menggambarkan sosok bu Mus dalam novel. Klausa-klausa tersebut muncul karena dalam T1 latar belakang dari karakter bu Mus ini tidak banyak diceritakan. Dalam T1 hanya diceritakan bahwa bu Mus lulus dari SKP. Alasan beliau memilih menjadi guru tidak diceritakan dengan jelas. Latar belakang serta alasan pendidikan bu Mus ini penting untuk diceritakan karena akan memberikan gambaran yang lebih lengkap dan jelas kepada pembaca terhadap salah satu karakter utama dalam novel.

\section{Wujud Variasi Keluasan Makna Interper- sonal T1:T3}

T1:T3 juga menunjukkan seluruh tingkat variasi, dari variasi nol hingga enam. Akan tetapi, jumlah kehadirannya tidak merata. Nilai variasi nol lebih mendominasi di antara variasi yang lain. Oleh karena itu, wujud variasi keluasan makna interpersonal T1:T3 tidak variatif. Di bawah ini ditunjukkan beberapa contoh dari wujud variasi nol dan satu.

Variasi Nol

$1.3 / 115$

T1 Satu jam dengannya terasa hanya satu menit

T3 Satu jam dengannya terasa hanya satu minit

\section{$1.4 / 321$}

T1 Ketika mendaftar badan mereka langsung diukur untuk tiga macam seragam harian dan dua macam pakaian olah raga.

T3 Ketika mendaftar badan mereka terus diukur untuk tiga jenis pakaian seragam dan dua jenis pakaian olah raga.

\section{$1.12 / 176$}

\begin{tabular}{ll}
\hline T1 & Apakah wajahnya seindah kuku-kukunya? \\
T3 & Apakah wajahnya seindah kuku-kukunya? \\
\hline
\end{tabular}

Contoh-contoh klausa translasional menunjukkan realisasi bentuk dan fungsi klausa yang sama. Selain itu, klausa-klausa tersebut juga merealisasikan elemen fungsional sistem gramatika MOOD yang sama. Oleh karena itu, klausa-klausa translasional tersebut merealisasikan tingkat variasi keluasan makna interpersonal bernilai nol.

\section{$1.14 / 7$}

T1 Sedangkan dua puluh Moran atau prajurit Masai sekujur tubuhnya dicat merah, mereka menggunakan penutup kepala berupa jalinan besar ilalang, membawa tombak panjang, dan mengenakan jubah berwarna merah yang sangat besar.

T3 Sedangkan dua puluh Moran atau prajurit Masai sekujur tubuhnya dicat merah.

Mereka menggunakan penutup kepala berupa jalinan besar ilalang, membawa tombak panjang, dan mengenakan jubah berwarna merah yang sangat besar.

Jika dilihat berdasarkan jumlah realisasi klausa, klausa 1.14/7 merupakan klausa yang tidak sama. Klausa T1 terealisasi dalam satu klausa kompleks dengan empat klausa sederhana, sedangkan klausa T3 terealisasi dalam dua klausa; satu klausa sederhana, dan satu klausa kompleks dengan tiga klausa sederhana. Namun, jika dilihat lebih teliti, klausa T1 dan T3 tidak menunjukkan adanya perbedaan realisasi elemen makna interpersonal. Klausa T3 hanya membagi klausa kompleks T1 menjadi dua bagian agar tidak terlalu panjang dan memudahkan pembaca
T3 untuk lebih memahami klausa tersebut. Oleh karena itu, meskipun satu klausa T1 terealisasi menjadi dua klausa T2, klausa translasional 1.14/7 merupakan wujud variasi keluasan makna interpersonal yang bernilai nol.

Variasi Satu

Wujud variasi satu T1:T3 dapat terjadi apabila terdapat perbedaan realisasi satu elemen fungsional sistem gramatika MOOD.

\section{$1.15 / 312$}

T1 Sisanya menunggu di bawah, siaga menangkap apa saja yang dilemparkan dari atas meja.

T3 Bakinya pula menunggu di bawah, siaga menunggu apa sahaja yang dilemparkan dari atas meja.

Klausa translasional 1.15/312 menunjukkan adanya penambahan realisasi elemen mood adjunct (kata "pula") pada klausa T3. Penerjemah menambahkan realisasi mood adjunct yang 
berupa kata penegas untuk menunjukkan intensitas makna.

\section{$1.4 / 303$}

T1 Tali merah bergulung-gulung keren sekali di bahu seragamnya itu.

T3 Tali merah bergulung-gulung di bahu bajunya itu.

Klausa 1.4/303 menunujukkan hilangnya realisasi adjunct pada klausa T3. Penerjemah menghilangkan klausa adjunct karena realisasi adjunct tersebut hanya merupakan bentuk opini tambahan yang jika dihilangkan sekalipun tidak akan mempengaruhi makna secara utuh.

$1.22 / 93$

\begin{tabular}{cc}
\hline T1 & Mereka tampak prihatin \\
T3 & Mereka kebimbangan \\
\hline
\end{tabular}

Klausa 1.22/93 merupakan contoh klausa translasional yang memiliki perbedaan realisasi elemen predikator. Pada klausa tersebut, penerjemah tidak merealisasikan predikator karena menggunaan penggunaan adjunct sudah mampu mewakili realisasi predikator dan adjunct. Selain itu, predikator pada klausa T1 juga merupakan bentuk verba untuk menyatakan opini, sehingga apabila verba tersebut dihilangkan tidak akan terlalu berpengaruh pada makna, tetapi akan berpengaruh pada kesan personal yang ditimbulkan klausa.

\section{Tingkat Variasi Keluasan Makna Interper- sonal T1, T2, dan T3}

Dalam penelitian ini, jumlah klausa yang dianalisis antara T1:T2 dan T1:T3 tidak sama. Pada T1:T2 jumlah data klausa yang terkumpul sebanyak 8449 unit makna setingkat kalimat. Pada T1:T3 jumlah data klausa yang terkumpul sebanyak 6082 unit makna setingkat kalimat.

Dari data yang diperoleh, jumlah data dengan variasi nol adalah 801 atau $9,48 \%$ untuk T1:T2 dan 5839 atau 96\% untuk T1:T3. Data yang tersisa adalah sebanyak 7648 klausa atau 90,52\% untuk T1:T2 dan 243 klausa atau 4\% untuk T1:T3. Data yang tersisa tersebut tersebar secara bervariasi pada skala 1-6. Pada T1:T2 data terbesar adalah sebanyak 4901 klausa atau $58 \%$. Data terbesar tersebut terdapat pada skala 6. Pada T1:T3 data terbesar adalah pada skala 0 . Secara lebih rinci, data tersebut dapat dilihat pada tabel 1 .

Tabel 1. Prosentase Tingkat Variasi Keluasan Makna Interpersonal

\begin{tabular}{ccccc}
\hline \multicolumn{1}{c}{ T1:T2 } & & \multicolumn{3}{c}{ T1:T3 } \\
\hline Variasi & Jumlah & Prosentase & Jumlah & Prosentase \\
\hline 0 & 801 & 9,48 & 5839 & 96 \\
1 & 909 & 10,76 & 173 & 2,84 \\
2 & 796 & 9,42 & 40 & 0,66 \\
3 & 330 & 3,91 & 9 & 0,15 \\
4 & 304 & 3,6 & 5 & 0,08 \\
5 & 408 & 4,83 & 7 & 0,12 \\
6 & 4901 & 58 & 9 & 0,15 \\
Total & 8449 & $100 \%$ & 6082 & $100 \%$ \\
\hline
\end{tabular}

Bila dibandingkan, berdasarkan tabel 1, wujud variasi keluasan makna interpersonal T1:T2 lebih variatif daripada T1:T3. Wujud variasi enam menempati posisi yang dominan, sebesar 58\%, untuk T1:T2 sedangkan variasi nol menempati posisi paling dominan, sebesar $96 \%$, untuk T1:T3. Prosentase terkecil adalah variasi empat, sebesar 3,6\%, untuk T1:T2 dan variasi lima, sebesar $0,12 \%$, untuk T1:T3.
Tabel 1 menunjukkan pula adanya perbedaan yang cukup besar antara wujud variasi teks terjemahan T2 dan teks terjemahan T3. Variasi keluasan makna T2 bernilai lebih besar daripada T3. Hal tersebut dapat terlihat bila data difokuskan berdasarkan kelompok variasi. Data yang diperoleh dapat dikelompokkan menjadi tiga kelompok, yaitu kelompok variasi rendah (skor $0-2$ ), sedang (skor 3-4) dan tinggi (skor 5-6).

Tabel 2. Kategori Variasi Keluasan Makna Interpersonal

\begin{tabular}{ccccc}
\hline Kategori Variasi & \multicolumn{2}{c}{ T1:T2 } & \multicolumn{2}{c}{ T1:T2 } \\
\hline & Jumlah & Prosentase & Jumlah & Prosentase \\
\hline Rendah & 2506 & 29,7 & 6052 & 99,5 \\
Sedang & 634 & 7,5 & 14 & 0,23 \\
Tinggi & 5309 & 62,8 & 16 & 0,26 \\
\hline
\end{tabular}


Tabel 2 menunjukkan dengan lebih jelas bahwa wujud variasi keluasan makna interpersonal T1:T2 masuk ke dalam variasi bernilai tinggi sedangkan T1:T3 masuk dalam variasi bernilai rendah. T1:T3 juga menunjukkan prosentase yang hampir mendekati $100 \%$ pada kategori variasi rendah, yang artinya hampir tidak terdapat variasi pada teks terjemahan T3.

Variasi yang terjadi pada T2 maupun T3 didasarkan pada penambahan dan pengurangan jumlah elemen makna interpersonal. Banyaknya elemen yang bertambah ataupun berkurang menentukan nilai dari variasi keluasan makna interpersonal. Pada T1:T2 jumlah klausa yang mengalami variasi (memiliki nilai 1-6) adalah
7648 klausa atau sebesar 90,52 \%. Jumlah tersebut artinya terdapat berbagai macam wujud variasi pada T1:T2. Hasil tersebut berbeda dengan T1:T3 yang lebih didominasi variasi nol, sehingga wujud variasi hanya berjumlah 243 klausa atau sebesar $4 \%$.

Jadi, berdasarkan pada tabel dan analisis data, dapat disimpulkan bahwa tingkat variasi keluasan makna interpersonal antara T1:T2 dan T1:T3 tidak sama. T1:T2 menunjukkan tingkat variasi tinggi, sedangkan T1:T3 menunjukkan tingkat variasi rendah. Hasil tersebut dapat dibuktikan pula dengan penghitungan hasil rerata yang disajikan pada tabel 3 .

Tabel 3. Rerata Tingkat Variasi Keluasan Makna Interpersonal T1:T2

\begin{tabular}{ccccc}
\hline Tingkat & Interval & Nilai Tengah & Frekuensi & f.xi \\
\hline 0 & $0-5$ & 2.5 & 801 & $2,002.50$ \\
1 & $5-10$ & 7.5 & 909 & $6,817.50$ \\
2 & $10-15$ & 12.5 & 796 & 9,950 \\
3 & $15-20$ & 17.5 & 330 & 5,775 \\
4 & $20-25$ & 22.5 & 304 & 6,840 \\
5 & $25-30$ & 27.5 & 408 & 11,220 \\
6 & $30-35$ & 32.5 & 4901 & $159,282.5$ \\
$\Sigma$ & & & 8449 & $201,887.5$ \\
\hline
\end{tabular}

Nilai rerata $=\frac{201887,50}{8449}=\mathbf{2 3 , 8 9}$

Dari perhitungan tersebut, diperoleh nilai rerata dari variasi keluasan makna interpersonal adalah 23,89, yang masuk dalam kategori interval 20-25 dan berasosiasi dengan nilai variasi tinggi.

Berdasarkan perhitungan, tingginya nilai variasi keluasan makna interpersonal T1:T2 disebabkan oleh tingginya prosentase variasi bernilai enam. Tingginya prosentase variasi enam juga mengakibatkan keluasan teks sasaran (TE) lebih besar daripada keluasan teks sumber
(SE). Kelebihluasan TE tersebut terindikasi dari frekuensi keluasan TE yang mencapai 3935 sementara keluasan SE hanya mencapai 3535 . Hal itu berarti penerjemah mewujudkan unit makna dan menciptakan makna baru pada klausa T2. Kelebihluasan dan kekurangluasan antara T1:T2 merupakan fenomena variasi dalam perwujudan makna dari satu sistem semiotika denotatif sebagai pewujud makna yang dikategorikan berkorelasi secara translasional.

Hasil perhitungan T1:T2 berkebalikan dengan T1:T3. Berikut ini disajikan tabel analisis T1:T3.

Tabel 4. Rerata Tingkat Variasi Keluasan Makna Interpersonal T1:T3

\begin{tabular}{ccccc}
\hline Tingkat & Interval & Nilai Tengah & Frekuensi & f.xi \\
\hline 0 & $0-5$ & 2.5 & 5839 & $14,597.50$ \\
1 & $5-10$ & 7.5 & 173 & $1,297.50$ \\
2 & $10-15$ & 12.5 & 40 & 500 \\
3 & $15-20$ & 17.5 & 9 & 157.5 \\
4 & $20-25$ & 22.5 & 5 & 112.5 \\
5 & $25-30$ & 27.5 & 7 & 192.5 \\
6 & $30-35$ & 32.5 & 9 & 292.5 \\
$\Sigma$ & & & 6082 & $17,150.00$ \\
\hline
\end{tabular}

Nilai rerata $=\frac{17150}{6092}=\mathbf{2 , 8 2}$

Berdasarkan perhitungan tersebut, diperoleh nilai rerata dari variasi keluasan makna inter-personal T1:T3 sebesar 2,82. Nilai tersebut ma-suk dalam kategori interval 0-5 yang berasosiasi dengan nilai variasi terendah. 
Jadi, Berdasarkan semua analisis tersebut, dapat dikatakan bahwa tingkat variasi keluasan makna interpersonal T1:T3 menduduki nilai terendah, meskipun masih menunjukkan adanya variasi dengan proporsi yang sangat kecil. Walaupun variasi yang muncul menduduki variasi terendah, nilai keluasan antara teks sumber (SE) dan teks sasaran (TE) jauh lebih tinggi TE. Diketemukan bahwa keluasan TE yang berjumlah 110 klausa melebihi keluasan SE, yang berjumlah hanya 87 klausa. Hal itu dapat diartikan bahwa di antara nilai variasi yang muncul, keluasan variasi tersebut lebih banyak ditemukan terjadi pada teks sasaran daripada teks sumber. Nilai keluasan yang berbeda menunjukkan adanya fenomena kelebihluasan dan kekurangluasan antara T1 dan T3. Pada kasus T1 dan T3, penerjemah mewujudkan lebih sedikit unsur makna dalam 87 klausa dan menciptakan lebih banyak makna, bahkan menghadirkan unsur makna yang baru dalam 110 klausa. Dengan demikian kelebihluasan dan kekurangluasan merupakan fenomena variasi pada perwujudan makna dari suatu sistem semiotika denotatif yang mewujud dalam teks yang berelasi secara translasional.

\section{Faktor-Faktor yang Mendorong Tingginya Tingkat Variasi Keluasan Makna Interpersonal T1:T2}

Berdasarkan analisis dan perhitungan statistik, diketahui bahwa tingkat variasi keluasan makna interpersonal T1:T2 atau antara teks Laskar Pelangi karya Andrea Hirata dan teks Rainbow Troops karya Angie Kilbane masuk dalam kategori variasi tinggi, dengan nilai rerata 23,89. Selain tingginya tingkat variasi keluasan makna interpersonal, nilai keluasan teks sasaran juga melebihi nilai keluasan teks sumber.

Hasil analisis tersebut tidak sejalan dengan sebagian besar teori penerjemahan yang dikemukakan oleh para ahli. Beberapa ahli penerjemahan selalu menyandarkan teks terjemahan atau teks sasaran harus selalu bersumber dari teks asli. Akan tetapi pada T2 penerjemah mewujudkan klausa-klausa baru yang tidak bersumber dari T1. Penerjemah juga menghadirkan tokoh baru dan mengubah sebagian alur cerita T1. Perubahan tersebut ditunjukkan dengan hadirnya 10 bab baru pada T2. Bab-bab baru inilah yang menjadi faktor tingginya nilai variasi enam pada T1:T2.

Hasil analisis teks T1 dan T2 menunjukkan pula bahwa seorang penerjemah memiliki hak untuk menciptakan karya terjemahan yang kreatif dan berbeda dari teks sumber. Hal tersebut bersesuaian dengan pandangan para fungsionalis yang berkeyakinan bahwa penerjemah memiliki otoritas dan hak otonom untuk menciptakan teks yang berbeda dari teks sumber.

Munculnya alur dan tokoh cerita merupakan salah satu langkah penerjemah untuk mengadaptasi cerita atau teks secara utuh, bukan hanya bersumber dari novel, tetapi juga bersumber dari cerita skenerio film dan hasil wawancara penerjemah dengan Andrea Hirata, penulis novel Laskar Pelangi. Selain itu, penerjemah juga ingin menghadirkan emosi yang sama kepada pembaca T2. Dalam T2 penerjemah juga ingin mengangkat isu tentang masih kurangnya perhatian pemerintah Indonesia terhadap hak memperoleh pendidikan bagi setiap anak Indonesia, yang merupakan tema utama novel Laskar Pelangi, menjadi lebih detail dan jelas. Untuk mencapai tujuan tersebut, penerjemah harus melakukan beberapa perubahan pada teks T2, sehingga memunculkan beberapa perbedaan yang cukup jelas antara T1 dan T2. Alasan dan pertimbangan tersebut diungkapkan penerjemah dalam bagian Tranlator's note yang terdapat pada bagian terakhir dalam novel Rainbow Troops.

Pada Translator's note dijelaskan pula bahwa novel Laskar Pelangi karya Andrea Hirata diterbitkan pada tahun 2005 sedangkan film Laskar Pelangi (secara internasional berjudul Rainbow Troops) diputar pada tahun 2008. Pemutaran film tersebut mendapat apresiasi yang sangat positif dari para penonton dan pengamat film, baik nasional maupun internasional, sehingga film ini mendapatkan banyak penghargaan di beberapa festival film yang diselenggarakan di dalam maupun di luar negeri. Fenomena inilah yang menyebabkan salah satu penerbit bentang pustaka serta Andrea Hirata pada tahun 2009 tertarik untuk membuat versi bahasa Inggris dari novel tersebut. Kemunculan film Rainbow Troops yang sudah lebih dahulu dikenal masyarakat menyebabkan penerjemah harus melakukan adaptasi cerita bukan hanya dari novel tetapi juga film. Jarak yang jauh antara teks sumber dan teks sasaran juga merupakan salah satu penyebab munculnya perbedaan antara T1 dan T2. Selain itu, selama proses penerjemahan penerjemah juga telah sering berdiskusi dan melakukan wawancara dengan penulis aslinya, Andrea Hirata. Diskusi dan wawancara tersebut mampu memberikan gambaran dan pandangan baru yang lebih jelas dan utuh tentang cerita dalam novel, karena cerita novel itu 
sendiri terinspirasi dari kehidupan masa kecil sang penulis. Penerjemah juga tinggal selama beberapa waktu di Belitong untuk bisa memperoleh penggambaran budaya dan kehidupan sosial masyarakat yang lebih nyata. Semua itu dilakukan oleh penerjemah untuk menghadirkan emosi yang sama dengan emosi Andrea Hirata ketika beliau menulis novel Laskar Pelangi.

Untuk mewujudkan pemahaman dan emosi yang sama antara pembaca T2 dengan pembaca $\mathrm{T} 1$, penerjemah memberikan gambaran yang lebih jelas dengan menghadirkan alur dan tokoh baru, serta memperkuat penggambaran tentang susahnya memperoleh pendidikan di Indonesia dalam teks T2. Jadi munculnya alur dan tokoh cerita baru pada teks T2 dimaksudkan penerjemah untuk memberikan gambaran yang lebih lengkap dan jelas kepada pembaca T2, yang minim pengetahuan tentang budaya Belitong dan kehidupan sosial masyarakat Indonesia serta belum menyaksikan versi layar lebar dari novel Laskar Pelangi (Rainbow Troops).

Selain beberapa alasan di atas, perubahan dilakukan oleh penerjemah karena bentuk alur cerita dan gaya bahasa dari teks sumber terkesan membingungkan pembaca, tidak sesuai dengan aturan gaya penulisan bahasa Indonesia yang benar serta tidak memenuhi syarat sebagai karya sastra yang baik. Pendapat tersebut dapat dilihat dengan sering munculnya beberapa klausa kompleks yang sangat panjang pada teks sumber. Hal tersebut membingungkan dan mempersulit pembaca untuk memaknai klausa tersebut. Gaya yang dipakai penulis juga bukan gaya penulisan sastra melainkan gaya bertutur secara lisan. Gaya penceritaan juga kurang sesuai karena menggunakan sudut pandang seorang Andrea Hirata dewasa, padahal dalam novel yang bercerita adalah Ikal (Andrea Hitara kecil). Kelemahan-kelemahan tersebut dicoba untuk diperbaiki oleh penerjemah, sehingga teks T2 bisa menjadi bacaan yang lebih baik dan mudah dipahami oleh pembaca $\mathrm{T} 2$, yang diharapkan penerjemah bukan hanya orang asing tetapi juga orang Indonesia sendiri.

Alasan-alasan dan pertimbangan-pertimbangan tersebut dibenarkan pula oleh Salman, kepala editor penerbit Bentang Pustaka dan Andrea Hirata sebagai penulis Laskar Pelangi. Berdasarkan penuturan Salman, perubahan cerita yang terdapat pada Rainbow Troops merupakan bentuk modifikasi yang dilakukan penerjemah yang telah disetujui oleh Andrea, karena pada Rainbow Troops, Andrea sendiri merupakan proofreader dari novel tersebut.
Oleh karena itu, dapat disimpulkan bahwa Andrea juga ikut terlibat dalam proses penerjemahn atau lahirnya Rainbow Troops. Pendapat Salman tersebut dibenarkan oleh Andrea Hirata dalam akun twitter dan facebooknya. Andrea ingin agar Rainbow Troops lebih baik secara kualitas keterbacaan, sehingga layak disebut sebagai karya sastra dan layak diterbitkan secara internasional serta layak dibaca oleh semua orang di seluruh dunia.

Beberapa alasan dan pertimbangan tersebut merupakan faktor yang mengakibatkan nilai keluasan T2 lebih tinggi daripada nilai keluasan T1. Perubahan, terutama penambahan klausa, yang dilakukan penerjemah tersebut bukan merupakan indikasi bahwa T2 bukan merupakan teks terjemahan dari T1. Perubahan dan adaptasi dilakukan oleh penerjemah, karena adanya perbedaan tujuan dan pembaca antara T1 dan T2.

Salah satu tujuan penerjemahan adalah untuk menghasilkan karya sastra bahasa inggris yang baik dan berkualitas kepada mahasiswa Indonesia yang belajar sastra inggris. Penerjemah dan penulis ingin agar mahasiswa Indonesia dapat mengkaji novel bahasa Inggris yang ditulis oleh orang Indonesia sendiri dan bercerita tentang bangsa serta masyarakat Indonesia. Untuk mewujudkan tujuan tersebut, T1 yang memperoleh banyak kritik harus diperbaiki dari segi kebahasaan dan kesusastraan. Oleh karena itu, penerjemah melakukan banyak perubahan dan perbaikan agar T2 menjadi karya yang lebih berkualitas dari $\mathrm{T} 1$ dan diterima oleh kalangan yang lebih luas secara internasional.

Selain faktor tujuan, faktor pembaca T2 juga merupakan alasan munculnya perubahan dan adapatasi. Pembaca T2 sebagian besar merupakan orang asing tidak memahami budaya dan kehidupan sosial masyarakat Belitong serta sikap pemerintah Indonesia terhadap rakyatnya. Oleh karena itu, untuk menciptakan kesan yang sama dengan pembaca $\mathrm{T} 1$, penerjemah melakukan beberapa perubahan dan adaptasi pada T2.

Jadi, dapat disimpulakan bahwa tingginya tingkat variasi keluasan makna interpersonal antara T1:T2 disebabkan oleh dua faktor, intrinsik dan ekstrinsik. Faktor intrinsik tersebut adalah munculnya penambahan dan penghilangan klausa pada T2, sedangkan faktor ekstrinsiknya adalah hadirnya film Laskar Pelangi yang mendahului lahirnya T2, fakor tujuan penerjemahan, dan faktor pembaca T2 yang berbeda dengan pembaca $\mathrm{T} 1$. 


\section{Faktor-Faktor yang Mendorong Rendahnya Tingkat Variasi Keluasan Makna Interpersonal T1:T3}

Berdasarkan perhitungan statistik tersebut, diketahui bahwa rerata tingkat variasi keluasan makna interpersonal T1:T3 atau antara teks Laskar Pelangi berbahasa Indoanesia dan Melayu berbeda bahkan berkebalikan dengan rerata tingkat variasi keluasan makna interpersonal T1:T2. Rerata tingkat variasi keluasan makna interpersonal T1:T3 masuk ke dalam kategori terendah, sebesar 2,82. Hasil rerata yang rendah ini didukung pula dengan tingginya nilai variasi nol, sebesar $96 \%$, yang berarti nilai variasi nol hampir mendekati $100 \%$. Hasil tersebut menunjukkan hampir tidak adanya variasi keluasan makna interpersonal pada teks T1 dan T3.

Rendahnya nilai variasi keluasan makna interpersonal T1:T3 disebabkan kurang variatifnya nilai variasi yang merupakan perwujudan dari realisasi elemen makna interpersonal antara T1 dan T3. Hasil yang kurang variatif ini disebabkan karena adanya persamaan sistem bahasa antara bahasa Indonesia dan Melayu. Bahasa Indonesia berakar dan merupakan perkembangan dari bahasa Melayu. Selain itu, novel Laskar Pelangi karya Andrea Hirata merupakan novel berbahasa Indonesia yang berlatar belakang masyarakat Belitung yang bahasa kesehariannya adalah bahasa Melayu. Oleh karena itu, novel Laskar Pelangi kental akan budaya Melayu serta memiliki gaya penceritaan bahasa Melayu.

Penerjemah T3 juga terkesan seperti menyalin kembali teks bahasa Indonesia ke dalam bahasa Melayu. Perubahan yang dilakukan penerjemah sebagian besar hanyalah berupa penambahan elemen adjunct yang tidak berpengaruh pada keutuhan makna dan tidak menimbulkan adanya makna baru. Perbedaan dalam T3 sebagian besar hanya merupakan perbedaan pilihan kata bukan perbedaan bentuk kata.

Selain beberapa alasan di atas, rendahnya tingkat variasi keluasan makna interpersonal T1:T3 adalah karena teks Lasykar Pelangi hanya merupakan produk alih bahasa. Pendapat tersebut diungkapkan oleh Salman ketika diwawancara di kantor Bentang Pustaka. Menurut Salman, teks Lasykar Pelangi merupakan bentuk inisiatif dari penerbit yang disetujui oleh Andrea. Akan tetapi, dalam proses alih bahasa tersebut, Andrea tidak terlibat secara langsung. Teks Laskar Pelangi juga hadir bersamaan dengan Rainbow Troops, sehingga dapat disimpulkan bahwa teks Lasykar Pelangi hanya menggunakan Laskar Pelangi sebagai sumber acuan pada proses alih bahasa.

Jadi, dapat disimpulkan bahwa rendahnya nilai rerata tingkat variasi keluasan makna interpersonal T1:T3 disebabkan adanya persamaan sistem bahasa, akar bahasa, serta kemiripan budaya antara bahasa Indonesia dengan bahasa Melayu. Selain itu, pandangan penerjemah untuk menyandarkan hasil penerjemahan hanya bersumber kepada teks asli, tanpa boleh melakukan kreativitas baru dari penerjemah juga merupakan salah satu faktor penyebab rendahnya rerata tingkat keluasan makna interpersonal T1:T3.

\section{SIMPULAN DAN SARAN}

Berdasarkan analisis data yang telah dilakukan, dapat ditarik beberapa kesimpulan dari penelitian ini.

Pertama, Wujud variasi keluasan makna interpersonal antara $\mathrm{T} 1$ dan $\mathrm{T} 2$ serta $\mathrm{T} 1$ dan $\mathrm{T} 3$ mencakup semua kemungkinan variasi dari variasi nol hingga variasi enam. Akan tetapi, nilai variasi yang paling dominan antara $\mathrm{T} 1$ dan $\mathrm{T} 2$ berbeda dengan $\mathrm{T} 1$ dan $\mathrm{T} 3$.

Kedua, Pada T1 dan T2 nilai variasi yang dominan adalah variasi enam (sebesar 58\%), sehingga rerata tingkat variasi keluasan makna interpersonal antara T1 dan T2 masuk ke dalam kategori tingkat rerata variasi tinggi. Hasil ini berarti bahwa penerjemah T2 banyak melakukan penambahan dan penghilangan unit makna setingkat klausa atau kalimat.

Ketiga, Pada T1 dan T3, wujud variasi keluasan makna interpersonal mencakup semua kemungkinan variasi pula, dari nilai variasi nol sampai enam. Akan tetapi, nilai variasi antara T1 dan T3 didominasi oleh nilai variasi nol (sebesar 96\%). Hal ini dapat diartikan bahwa penerjemah T3 melakukan proses penerjemahan dengan bersumber secara utuh kepada teks asli. Penerjemah tidak melakukan penambahan makna setingkat klausa.

Keempat, tingginya tingkat variasi keluasan makna interpersonal antara T1:T2 disebabkan oleh faktor intrinsik dan ekstrinsik. Faktor intrinsik yang mendorong tingginya tingkat variasi T1:T2 tersebut yaitu; (1) adanya penambahan dan penghilangan realisasi klausa yang dilakukan oleh penerjemah dan (2) perbedaan sistem bahasa antara bahasa Indonesia dan bahasa Inggris. Faktor ekstrinsik yang mendorong tingginya tingkat variasi T1:T2 yaitu; (1) hadirnya film Laskar Pelangi sebagai intertekstual konteks pada proses penerjemahan, (2) tujuan 
penerjemahan yang berbeda dengan tujuan penulisan novel, dan (3) pembaca T2 yang memiliki perbedaan latar belakang pengetahuan dengan pembaca T1.

Kelima, Rendahnya tingkat variasi keluasan makna interpersonal antara T1 dan T3 disebabkan pula oleh faktor intrinsik dan ekstrinsik. Faktor intrinsik yang mendorong rendahnya tingkat variasi T1:T3 yaitu; (1) tidak adanya penambahan realisai elemen makna setingkat klausa yang dilakukan oleh penerjemah dan (2) adanya kedekatan hubungan dan persamaan akar bahasa dan budaya antara bahasa Indonesia dan Melayu. Faktor ekstrinsik yang mendorong rendahnya tingkat variasi T1:T3 yaitu; (1) tujuan penerjemahan T1 ke dalam T3 hanyalah untuk alih bahasa dan melestarikan bahasa Melayu dan (2) faktor pembaca T3 yang memiliki latar belakang pengetahuan yang hampir sama dengan pembaca T1.

Berdasarkan kesimpulan yang dipaparkan, dapat diketahui bahwa penelitian ini hanya berfokus pada realisasi makna interpersonal dan fator-faktor yang mendorong tinggi/rendahnya tingkat variasi keluasan makna. Penelitian ini belum menyentuh aspek dan sifat makna yang lain juga tidak menyentuh kajian budaya dalam penerjemahan. Oleh karena itu, penelitian selanjutnya dapat berfokus pada aspek makna yang lain; makna ideasional dan terkstual, serta sifat makna lainnya; kedalaman dan ketinggian makna. Kajian yang lain juga dapat diarahkan untuk berfokus pada aspek sosio-budaya, sehingga bukan hanya membahas pada tataran makna denotatif teks, tetapi lebih pada tataran makna semiotika atau konotatif teks.

\section{DAFTAR PUSTAKA}

Aziz, S. H. A. (2011). Bahasa Melayu I edisi kedua. Malaysia: Oxford Fajar Sdn. Bhd

Alwi, H., Darajowidjojo, S., \& Lapoliwa, H. et al. (2003). Tata bahasa baku bahasa Indonesia. Edisi ketiga. Jakarta: Balai Pustaka

Bassnett, S. \& Trivedi, H. (1999). Post-colonial translation. New York: Routledge

Butt, D. Fahey, R., \& Feez S. et al. (2000). Using functional grammar: an explorer's guide $2^{\text {nd }}$ edition. Sydney: National Centre for English Language Teaching and Research Macquire University
Chaer, A. (2009). Sintaksis bahasa indonesia: pendekatan proses. Jakarta: PT. Rineka Cipta

Hatim, B \& Munday, J. (2004). Translation: an advanced resource book. New York: Routledge

Halliday, M.A.K. \& Hasan, R. (1992). Bahasa, konteks, dan teks. (Terjemahan Asruddin Barori Tou). Australia: Deakin Univrsity (Buku asli diterbitkan tahun 1985)

Halliday, M.A.K \& Mathiessen Christian M.I.M. (2004). An introduction to functional grammar $3^{\text {rd }}$ edition. America: Oxford University Press Inc.

Hirata, A. (2005). Laskar pelangi. Yogyakarta: PT. Bentang Pustaka

Hirata, A. (2009a). Rainbow troops. (Terjemahan Angie Kilbane). Yogyakarta: PT. Bentang Pustaka.

Hirata, A. (2009b). Lasykar Pelangi. (Terjemahan Ida Munira Abu Bakar). Selangor: PTS Litera Utama Sdn

Jakobson, R. (1987). On linguistic aspects of translation dalam Pomorska, K. \& Rudy, S. (Eds.), Language in Literature (pp. 428-435). Massachusetts: Harvard University Press.

Kesuma, T.M. J. (2009). Metode linguistik menurut perspektif Dr. Sudaryanto dalam P. Ari Subagyo \& Dusartomo Macaryus (Eds), Peneroka Hakikat Bahasa: Karangan Muhibah untuk Sudaryanto (pp. 15-25). Yogyakarta: Penerbit Universitas Sanata Dharma

Martin, J.R. (1992). English text system and structure. Amsterdam: John Benjamin Publishing Co

Moleong, L.J. (2012). Metodologi penelitian kualitatif (Rev. ed). Bandung: PT. Remaja Rosdakarya

Ramlan, M. (1983). Sintaksis. Yogyakarta: C.V. Karyono

Santoso, R. (2003). Semiotika sosial: pandangan terhadap bahasa. Surabaya: Pustaka Eureka

Sinar, T. S. (2007). Phasal and experiential realizations in lecture discourse. 
LingTera, 2 (1), Mei 2015 - 26

Apriliana Hapsari, Asruddin Barori Tou

Medan: Kopertis Wilayah I SumutNAD

Tou, A. B. (2008). The translatics of translation. Journal of Modern Languages Faculty of Language and Linguistics University of Malay, 18, 15-40 http://www.bangkabelitungprov.go.id/content/vi ew/146/5/lang,id_ID/

www.andrea-hirata.com

andreahiratathewriter@gmail.com

Andrea Hirata on Facebook

Andrea Hirata on Twitter 